\title{
A Comparative Study on Chemical and Electrochemical Degradation of Reactive Blue 4 Dye
}

\author{
Patricia A. Carneiro, Cecílio S. Fugivara, Raquel F. P. Nogueira, Nivaldo \\ Boralle, Maria V. B. Zanoni* \\ Instituto de Química - UNESP, C. P. 355, 14801-970 Araraquara, SP, Brazil \\ Received 02 September 2002; accepted in revised form 29 November 2002
}

\begin{abstract}
The degradation of a reactive blue 4 dye in acidic solution has been compared using electrochemical reduction and oxidation at reticulated vitreous carbon electrode (RVC) and $\mathrm{Ti} / \mathrm{SnO}_{2} / \mathrm{SbO}_{\mathrm{x}}(3 \% \mathrm{~mol}) / \mathrm{RuO}_{2}(30 \% \mathrm{~mol})$ electrodes and photo-Fenton method under UV irradiation. The reduction of RB4 dye at $-0.6 \mathrm{~V}$ on RVC electrode results in $50 \%$ of color removal and up to $64 \%$ of TOC removal. The direct oxidation of RB4 dye at $+1 \mathrm{~V}$ on $\mathrm{RVC}$ promotes only the oxidation of amine group and there is no color removal. On $\mathrm{SnO}_{2}$ electrode, 58\% TOC was removed and the decolorization is around $100 \%$ after 1 hour of electrolysis at $2.4 \mathrm{~V}$ indicating good efficiency. Best performance was obtained by photo-Fenton method that indicates $80 \%$ elimination of TOC and $100 \%$ of color removal but the method requires oxidant addition and time of rest to remove the generated residues.
\end{abstract}

Keywords: anthraquinone dyes, electro-reduction, electro-oxidation, Photo-Fenton, Reactive Blue 4.

\section{Introduction}

Reactive Blue 4 dye (Fig. 1) is an anthraquinone-based chlorotriazine dye very important in dyeing of cellulosic fabrics. Fixation of the dye molecule onto the fiber occurs via covalent bonding by nucleophilic displacement of the halide substituents at the hydroxyl group on cellulose. Stable bonds are formed, but during the alkaline dyeing process hydrolysis of the dye occurs as a side reaction

\footnotetext{
* Corresponding author. E-mail address: boldrinv@iq.unesp.br
} 
leading to dye inactivation [1]. Once dyeing is completed, the material is washed several times to remove unfixed and hydrolysed dye. Therefore, the reactions necessary to introduce the substances onto the fiber do not run to total completion and residual reactive and hydrolysed dyes are left in the process water and are discharged in the wastewater leaving the site [2]. This wastewater is discharged either to sewer, which is then treated by municipal sewage treatment works, or directly to watercourse (in some countries). Despite the problems, reactive dyes are very effective and are the main group of dyes [2]. Therefore, their high world consumption has attracted the critical attention of the public and the authorities with respect to the toxicological and environmental aspects of the reactive dyes[3-4].

A $\quad$ B

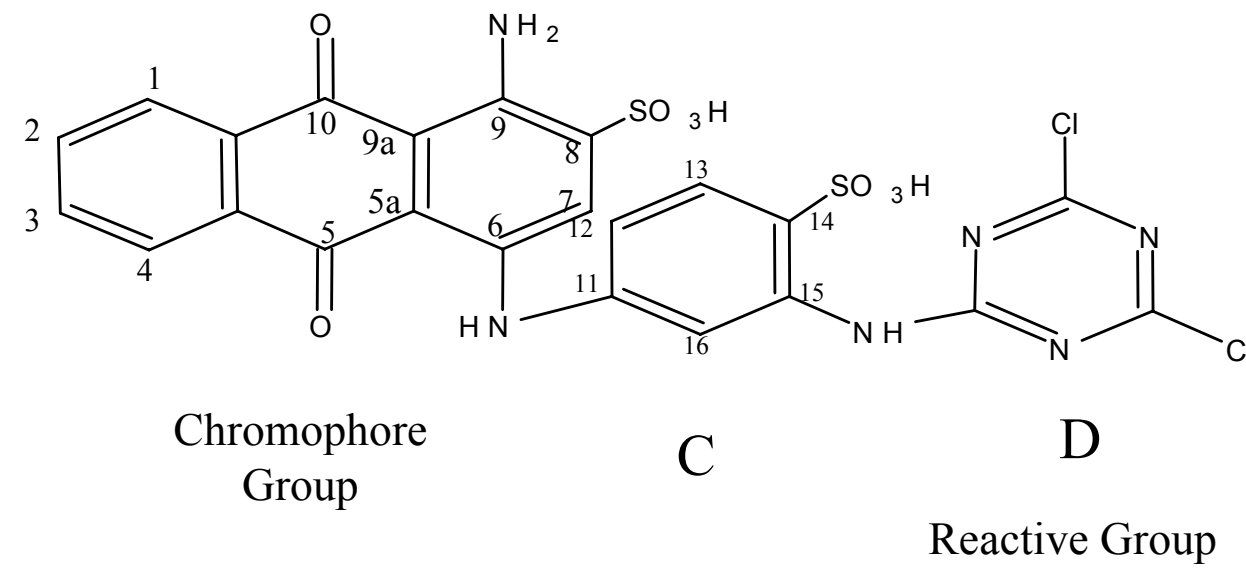

Figure 1. Molecular structure of Reactive Blue 4 dye.

The various processes used for the pre-treatment of dye bearing wastewater are based on physical or chemical treatment processes. They include physicochemical flocculation, electroflotation, membrane-filtration, electrokinetic coagulation, ion-exchange, irradiation, precipitation and other treatment using activated carbon [5]. Over the past few years, alternative methods [6-10] for dye treatment have been investigated, including chemical oxidation with reagents such as: ozone, hydrogen peroxide, ozone/UV, hydrogen peroxide/UV and Fenton's reagent [hydrogen peroxide + Fe (II)]. Relatively fewer studies have 
been conducted on the application of methods based on electrochemical processes for the treatment of textile wastewater. Some studies [11-15] have shown that electrochemical oxidation with or without UV light as method for dye degradation have shown several advantages, but the most electrochemical studies involving reduction of reactive dyes are based on mercury electrode [16-19] and the decolorization and mineralization by electrochemical treatment are rarely studied.

The aim of this work was to compare the effectiveness of direct electro-reduction and electro-oxidation of Reactive Blue 4 dye with conventional chemical oxidation process. The electrochemical degradation of dye solutions was investigated using reticulated vitreous carbon electrode and $\mathrm{Ti} / \mathrm{SnO}_{2} / \mathrm{SbO}_{\mathrm{x}}$ $(3 \% \mathrm{~mol}) / \mathrm{RuO}_{2}(30 \% \mathrm{~mol})$ electrodes at acidic solutions $(\mathrm{pH}=2.0)$. The chemical oxidation was performed using Fenton's reagent as oxidant under UV irradiation in acidic medium at $\mathrm{pH} 2.5$.

\section{Experimental}

\section{Electrochemical Procedures}

The electrochemical measurements were carried out using a Potentiostat/Galvanostat EG\&G PARC model 283 controlled by the Electrochemical 270 software. The cell used for cyclic voltammetric experiments was of a three electrode type, with two compartments. The working electrode was a glassy carbon (PARC) disc, of $0.28 \mathrm{~cm}^{2}$ area, polished between experiments. A carbon auxiliary electrode and an $\mathrm{Ag} / \mathrm{AgCl}\left(3.0 \mathrm{~mol} \mathrm{~L}^{-1}\right)$ electrode were used as the counter and reference electrodes, respectively. The controlled potential electrolysis were carried out using a three compartment cell, where a reticulous glassy carbon electrode $\left(2.5 \mathrm{~cm}^{2}\right)$ or $\mathrm{Ti} / \mathrm{SnO}_{2} / \mathrm{SbOx}$ $(3 \% \mathrm{~mol}) / \mathrm{RuO}_{2}(30 \% \mathrm{~mol})$ electrode $\left(57.4 \mathrm{~cm}^{2}\right)$ separated by a fine glass sinter, acted as working electrode. A $4.0 \mathrm{~cm}^{2} \mathrm{Pt}$ gauzes acted as anode in the other compartment and $\mathrm{Ag} / \mathrm{AgCl}\left(3.0 \mathrm{~mol} \mathrm{~L}^{-1}\right)$ was used as reference electrode.

The dye degradation was conducted by aliquots transference of RB4 dye solution submitted to different time of electrolysis at defined experimental conditions. 
TOC and color of the solution were measured using the Total Organic Carbon Analyzer (Shimadzu 5000A) and a diode array UV-VIS spectra recorded at a HP 8453 spectrophotometer operating from 190 to1000 nm in quartz cell.

The products generated after total electrolysis were also analyzed using previous solid-phase extractions. A Waters Associates Sep-Pack C18 cartridge was prewashed with ethanol, water and ethanol. Aliquots of the electrolyzed sample were diluted with water and passed through the cartridge. Elution of the products was effected with ethanol. The solvent was evaporated in a Labconco Freeze Dry System Frezone. The products were checked by IR spectroscopy in a spectrometer Nicolet - Impact 400 and NMR spectroscopy in a spectrometer Nuclear Magnetic Ressonance INOVA-500 at $500 \mathrm{MHz}$ using TMS as the internal standard.

All pH measurements were made with a Corning $555 \mathrm{pH}$ meter with a glass electrode which had been calibrated previously. Supporting electrolytes and stock solutions were prepared in deionized water from a Milli-Q system (Millipore). All the solutions were prepared with Millipore Milli-Q water and analytical grade reagents. Stock solutions of RB4 were prepared from solid samples obtained from Aldrich without further purification (35\% purity). The studies were carried out in $\mathrm{HCl} / \mathrm{KCl}$ solution $\left(0.2 \mathrm{~mol} \mathrm{~L}^{-1} \mathrm{pH} 2.0\right)$ and $\mathrm{Na}_{2} \mathrm{SO}_{4} / \mathrm{H}_{2} \mathrm{SO}_{4}$ solution $\left(0.2 \mathrm{~mol} \mathrm{~L}^{-1} \mathrm{pH} 2.0\right)$.

The $\mathrm{Ti} / \mathrm{SnO}_{2} / \mathrm{SbOx}(3 \% \mathrm{~mol}) / \mathrm{RuO}_{2}(30 \% \mathrm{~mol})$ electrodes were prepared by thermal decomposition of the $\mathrm{SnCl}_{2}, \mathrm{SbCl}_{3}$ and $\mathrm{RuCl}_{3}$ solutions at $450{ }^{\circ} \mathrm{C}$ on spirals of tin clean and polished. The application on the metal was made by painting the substrate. The painting, drying and heating steps were repeated eight times. The coating was annealed at $450{ }^{\circ} \mathrm{C}$ for 1 hour in air.

\section{Photo-Fenton Procedures}

The potassium ferrioxalate, used as source of Fe (II), was synthesized through the reaction of potassium oxalate $\left[\mathrm{K}_{3} \mathrm{Fe}\left(\mathrm{C}_{2} \mathrm{O}_{4}\right) \cdot 3 \mathrm{H}_{2} \mathrm{O}\right]$ and iron chloride (III), as described in the literature [20]. The salt was re-crystallized three times in deionized water and in the light absence. Aqueous $0.25 \mathrm{~mol} \mathrm{~L}^{-1}$ ferrioxalate stock 
solution was prepared and stored in the dark at room temperature. For the experiments with artificial irradiation the $\mathrm{pH}$ of the $\mathrm{RB} 4$ dye solution, previously prepared, was adjusted to $\mathrm{pH} 2.5$ with of $\mathrm{H}_{2} \mathrm{SO}_{4}$ or $\mathrm{NaOH}$ and proper amounts of potassium ferrioxalate $(\mathrm{FeOx})$ and hydrogen peroxide $30 \mathrm{w} \%$ were added in this order.

Experiments were performed using an upflow photoreactor constructed using a pyrex glass cylinder of $52.9 \mathrm{~mm}$ of internal diameter and $30 \mathrm{~cm}$ height. The irradiation source was a $15 \mathrm{~W}$ blacklight lamp, with maximum emission at 365 $\mathrm{nm}$ [21]. The light intensity of the lamp was measured in the wavelength of 365 $\mathrm{nm}$ (359 to $371 \mathrm{~nm}$ ) using a cole parmer radiometer (model 9811-50). The photoreactor was operated in a recirculation mode using a peristaltic pump (Ismatec IPC), as illustrate Fig. 2. Characteristics of the photoreactor are presented in Table 1. All the measurements were obtained using a flow rate of 36 $\mathrm{mL} \min ^{-1}$ (residence time $\left.=11 \mathrm{~min}\right)$.

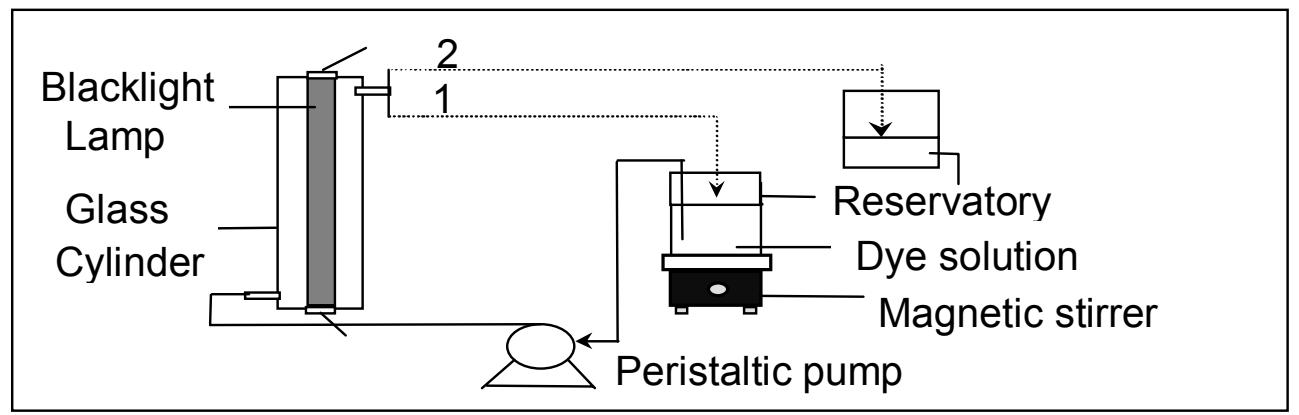

Figure 2. Schematic representation of the photoreactor used for the evaluation of photodegradation parameters: 1) recirculation mode and 2) single pass mode.

Table 1. Characteristics of the reactor. $\mathrm{D}_{\text {int. }}=$ internal diameter; $\mathrm{V}_{\text {reactor }}=$ volume of the photoreactor; $\mathrm{V}_{\text {total }}=$ total volume for photodegradation; $\rho=$ flow rate; $\bar{I}=$ average light intensity of the lamp at $365 \mathrm{~nm}$ and $\mathrm{D}_{\text {lamp }}=$ diameter of the lamp.

\begin{tabular}{ccccccc}
$\begin{array}{c}\mathrm{D}_{\text {int. }} \text { cylinder } \\
(\mathrm{mm})\end{array}$ & $\begin{array}{c}\text { Wavelength } \\
(\mathrm{mm})\end{array}$ & $\begin{array}{c}\mathrm{V}_{\text {reactor }} \\
(\mathrm{mL})\end{array}$ & $\begin{array}{c}\mathrm{V}_{\text {total }} \\
(\mathrm{mL})\end{array}$ & $\begin{array}{c}\rho \\
\left(\mathrm{mL} \mathrm{min}^{-1}\right)\end{array}$ & $\begin{array}{c}\bar{I}_{365} \\
\left(\mathrm{~mW} \mathrm{~cm}^{2}\right)\end{array}$ & $\begin{array}{c}\mathrm{D}_{\text {lamp }} \\
(\mathrm{mm})\end{array}$ \\
\hline 52.9 & 9.1 & 400 & 1000 & 36 & 2.62 & 37.05
\end{tabular}

\section{Results and Discussion}


The electrochemical behavior of $1.0 \times 10^{-3} \mathrm{~mol} \mathrm{~L}^{-1} \mathrm{RB} 4$ dye in $\mathrm{HCl} / \mathrm{KCl} \mathrm{pH} 2.0$ is illustrated in Fig. 3. Cyclic voltammograms (Fig.3) have shown that the reactive dye is reduced in three cathodic peaks at $-0.36 \mathrm{~V}$ (peak I) due to anthraquinone group reduction to hydroquinone derivative after 2 electron transfer. Two other peaks are observed at $-0.89 \mathrm{~V}$ (peak II) and $-1.0 \mathrm{~V}$ (peak III) attributed to bis-chlorotriazine reduction via $-\mathrm{C}-\mathrm{Cl}$ bond cleavage [16]. Reactive Blue 4 is oxidized on glassy carbon electrode in a single step due to oxidation of the secondary amine group leading to the imide derivative [22], as shown in Fig. 3.

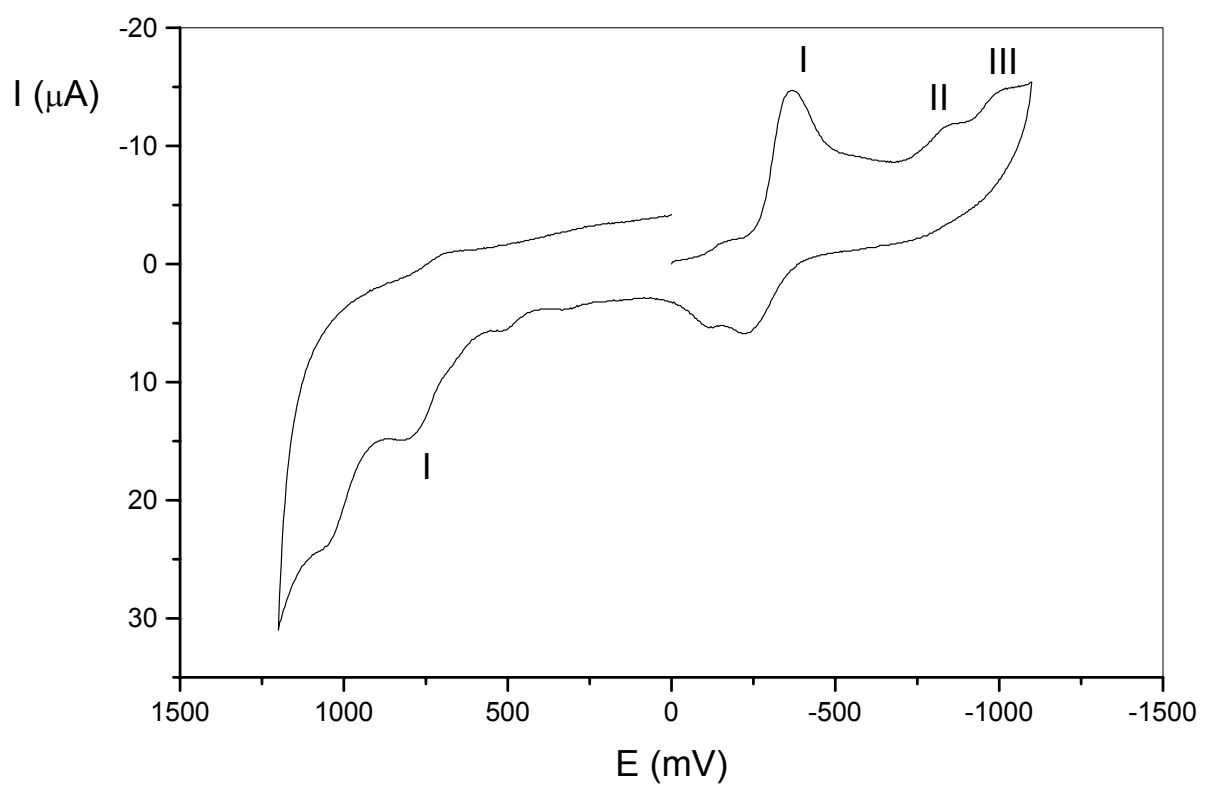

Figure 3. Cyclic voltammograms of the reduction (A) and oxidation (B) of $1.0 \times 10^{-3} \mathrm{~mol} \mathrm{~L}^{-1} \mathrm{RB} 4$ dye in $\mathrm{HCl} / \mathrm{KCl}$ solution 0.2 mol L ${ }^{-1} \mathrm{pH} 2.0$ in vitreous carbon disc electrode, $\mathrm{v}=0.05 \mathrm{~V} \mathrm{~s}^{-1}$.

In order to check the relative importance of direct oxidation or reduction in the decolorization of anthraquinone based dyes, a series of experiments was performed using controlled potential electrolysis testing two types of electrodes: reticulated vitreous carbon and $\mathrm{Ti} / \mathrm{SnO}_{2} / \mathrm{SbOx}(3 \% \mathrm{~mol}) / \mathrm{RuO}_{2}(30 \% \mathrm{~mol})$. The former is a three-dimensional electrode with a great surface area that enhances the energy efficiency of the electrochemical reaction [23]. The later is also porous, but it is a $\mathrm{DSA}^{\circledR}$ type of anode where oxidation reactions usually will be acting on dye via $\mathrm{HO}^{\bullet}$ radicals on the surface, which can lead to better performance in organic and inorganic species degradation. 
The performance of reticulated vitreous carbon electrode in the color removal of $2.5 \times 10^{-4} \mathrm{~mol} \mathrm{~L}^{-1} \mathrm{RB} 4$ dye solution in $0.2 \mathrm{~mol} \mathrm{~L}^{-1} \mathrm{HCl} / \mathrm{KCl}$ by reduction process at $-0.60 \mathrm{~V}$ can be observed in Fig. 4 .

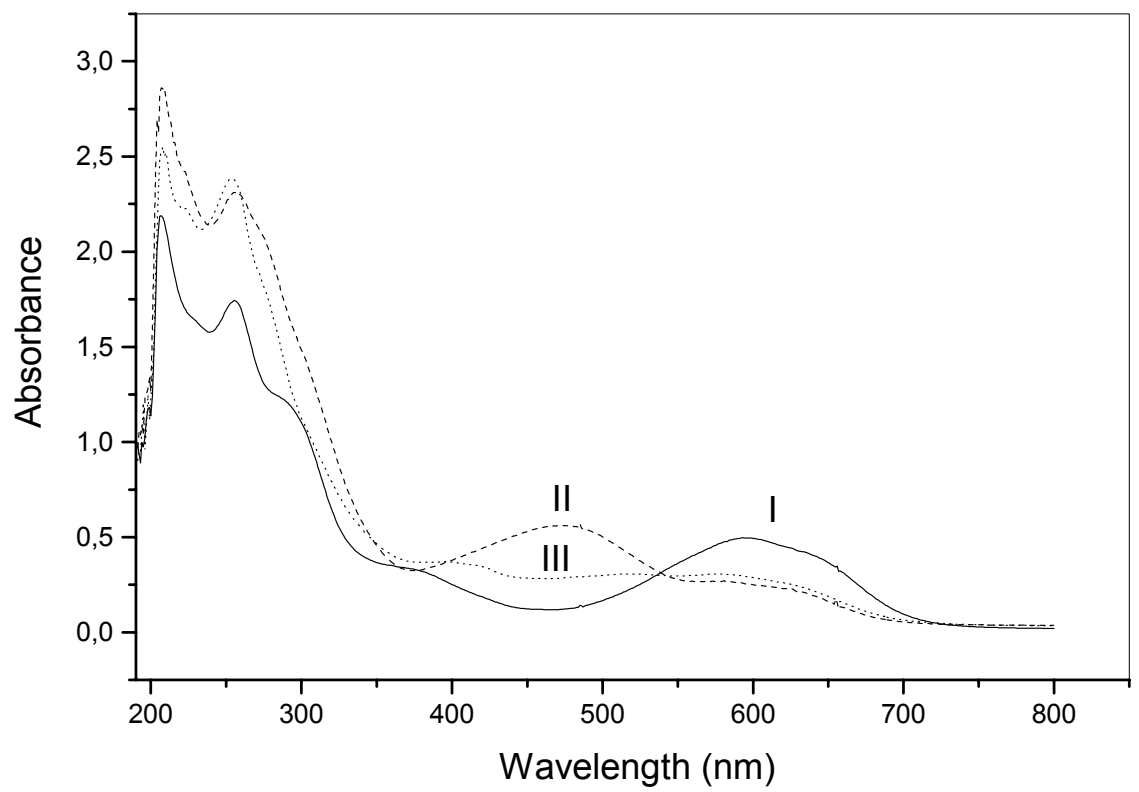

Figure 4. Absorption spectra recorded for $2.5 \times 10^{-4} \mathrm{~mol} \mathrm{~L}^{-1} \mathrm{RB} 4$ dye in $\mathrm{HCl} / \mathrm{KCl}$ $0.2 \mathrm{~mol} \mathrm{~L}^{-1} \mathrm{pH}$ 2.0: (-) before and (---) immediately after 3 hours of electrolysis at $\mathrm{E}=-0.60 \mathrm{~V}$ and $(\cdots \cdots \cdot)$ after rest solution of 10 hours.

Representative UV-Vis spectra obtained for original dye (Curve I) displayed absorption bands at $595 \mathrm{~nm}, 370 \mathrm{~nm}$ and $296 \mathrm{~nm}$ characteristics of the anthraquinone group and another one at $256 \mathrm{~nm}$ that is attributed to the aromatic character and chlorotriazine group. The UV-VIS spectrum immediately after the electrolysis (Curve II of Fig. 4) shows the accentuated decreasing of the typical bands attributed to the anthraquinone group, displaying absorption band only at $256 \mathrm{~nm}$ and a new peak at $475 \mathrm{~nm}$ due to semiquinone intermediate generation [1]. Both absorption bands of the chromophore or intermediate compounds are completely extinguished after a rest of 10 hours in solution, as shown in curve III of Fig. 4. 


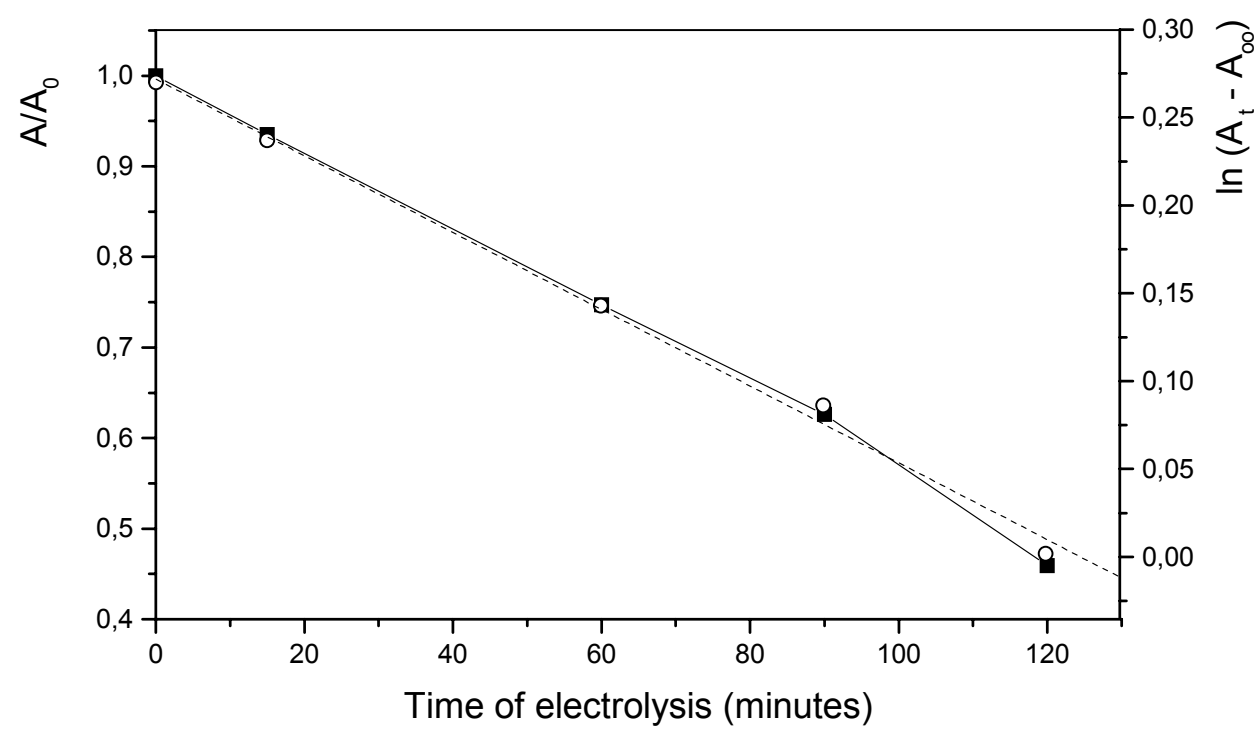

Figure 5. Fractional conversion of $2.5 \times 10^{-4} \mathrm{~mol} \mathrm{~L}^{-1} \mathrm{RB} 4$ dye electrolysed at $\mathrm{E}=$ $0,60 \mathrm{~V}$ on reticulated vitreous carbon electrode in $\mathrm{HCl} / \mathrm{KCl}$ solution $0.2 \mathrm{~mol} \mathrm{~L}^{-1}$ pH 2.0; (A) (- - $)$ A/A plot at 595nm; (B) (---O--) $\ln \left(\mathrm{A}_{\mathrm{t}}-\mathrm{A} \infty\right)$ plot at $595 \mathrm{~nm}$.

In Fig. 5A, performance of the reticulated carbon cathode in color removal is evaluated as Fractional Conversion $(f)$ of the dye and plotted in a time-dependent scale for electrolysis carried out in different times. Fractional conversion was evaluated as the ratio of dye absorption variation at time $t(A)$ to the initial dye concentration $\left(\mathrm{A}_{0}\right)$ in solution at $\mathrm{t}=0$. Each electrolysis was interrupted at controlled time and the solutions examined by spectrophotometric analysis every 15 min up to a maximum of 3 hours, restarted successively with new solution under identical conditions. RB4 dye obeys the Beer's Law for dye concentrations up to $1.5 \times 10^{-4} \mathrm{~mol} \mathrm{~L}^{-1} ; \varepsilon=1.324 \times 10^{4} \mathrm{~mol} \mathrm{~L}^{-1} \mathrm{~cm}^{-1}$ at $\lambda=595 \mathrm{~nm}$. The fractional conversions indicate $61 \%$ removal of color when $50 \mathrm{~mL}$ of the dye are electrolyzed for $120 \mathrm{~min}$. The dependence of the initial degradation rate was evaluated from slopes of the curves $\ln \left(A-A_{\infty}\right)$ as function of time $(s)$. The process followed a first order kinetic and respective rate degradation constant $(\mathrm{k})$ obtained from values of $\ln \left(\mathrm{A}-\mathrm{A}_{\infty}\right)$ vs. time and initial degradation rate $\left(\mathrm{V}_{\text {initial }}\right.$ decolorization) was calculated and the parameters are shown in Table 2. These results illustrate that dye degradation by electrolytic reduction is highly effective for decolorization at acidic condition. 
Table 2. Kinetic parameters estimated from media electrochemical and photochemical experiments for RB4 dye.

\begin{tabular}{lcccc}
\hline \multicolumn{1}{c}{ Parameters } & $\begin{array}{c}\text { Reduction* } \\
\text { on RVC } \\
\text { electrode }\end{array}$ & $\begin{array}{c}\text { Oxidation** } \\
\text { on } \mathrm{RVC} \\
\text { electrode }\end{array}$ & $\begin{array}{c}\text { Oxidation*** } \\
\text { on } \mathrm{SnO}_{2} \\
\text { electrode }\end{array}$ & $\begin{array}{c}\text { Photo-Fenton } \\
\text { process**** }\end{array}$ \\
\hline \% TOC removal (75 min.) & 63.8 & 56.7 & 57.6 & 79.8 \\
\hline \% Color removal $(25$ min.) & 50.0 & 2.00 & 97.4 & 72.1 \\
\hline $\begin{array}{l}\text { Initial degradation TOC rate } \\
(\text { ppm min }\end{array}$ ) $\times 10^{-3}$ & ----- & ------ & ----- & 44.6 \\
\hline $\begin{array}{l}\text { Initial decoloration rate } \\
\left(\text { mol L }^{-1} \text { min }^{-1}\right) \times 10^{-3}\end{array}$ & 4.22 & ---- & 56.0 & 14.1 \\
\hline $\begin{array}{l}\text { Decoloration constant } \\
\left(\text { min }^{-1}\right) \times 10^{-3}\end{array}$ & 2.18 & ---- & 112 & 104 \\
\hline
\end{tabular}

$\mathrm{RVC}$ - reticulated vitreous carbon electrode; $\mathrm{SnO}_{2}-\mathrm{Ti} / \mathrm{SnO}_{2} / \mathrm{SbOx}(3 \% \mathrm{~mol}) / \mathrm{RuO}_{2}(30 \% \mathrm{~mol})$ electrode; * in $\mathrm{HCl} / \mathrm{KCl} 0.2 \mathrm{~mol} \mathrm{~L}^{-1} \mathrm{pH} 2.0, \mathrm{E}=-0.60 \mathrm{~V}$, [dye] $=2.8 \times 10^{-3} \mathrm{~mol} \mathrm{~L}^{-1}, \mathrm{t}=2$ hours; $* *$ in $\mathrm{HCl} / \mathrm{KCl} 0.2 \mathrm{~mol} \mathrm{~L}^{-1} \mathrm{pH} 2.0, \mathrm{E}=+1.0 \mathrm{~V}$, [dye] $=2.8 \times 10^{-3} \mathrm{~mol} \mathrm{~L}^{-1}, \mathrm{t}=3$ hours; ***in $\mathrm{Na}_{2} \mathrm{SO}_{4} 0.2 \mathrm{~mol} \mathrm{~L}{ }^{-1} \mathrm{pH} 2.0, \mathrm{E}=+2.4 \mathrm{~V}$, [dye] $=2.8 \times 10^{-3} \mathrm{~mol} \mathrm{~L}^{-1}, \mathrm{t}=1$ hour; $* * * *$ Photochemical oxidation with artificial irradiation: $\mathrm{I}=2.62 \mathrm{mWcm}^{-2},[\mathrm{FeOx}]=1.00 \times$ $10^{-3} \mathrm{~mol} \mathrm{~L}^{-1} ;\left[\mathrm{H}_{2} \mathrm{O}_{2}\right]=10.0 \times 10^{-3} \mathrm{~mol} \mathrm{~L}^{-1}$, [dye $]=0.10 \times 10^{-3} \mathrm{~mol} \mathrm{~L}^{-1}, \mathrm{pH}=2.5$.

The products generated after 3 hours of electrolysis were also analyzed by IR and NMR spectroscopy. IR absorptions at 3445, 1724, 1623, 1572, 1491, 1407 and $880 \mathrm{~cm}^{-1}$ were attributed to hydroxyl, carbonyl, aromatic and chlorotriazinyl groups, respectively, compatible with the structure of the original dye (Fig.1). The most remarkable difference in the IR absorptions obtained for original dye and its electrolysed product at $\mathrm{pH} 2.0$ was the disappearance of the absorptions at $1745 \mathrm{~nm}(\mathrm{C}=\mathrm{O}$ bond $)$ and the occurrence of a new band at $1121 \mathrm{~cm}^{-1}(\mathrm{C}-\mathrm{OH}$ bond), indicating the reduction of carbonyl group from quinone group and generation of hydroquinone. The disappearance of the band at $881 \mathrm{~cm}^{-1}$, attributed to the chlorotriazinyl group, is also observed indicating that the probable cleavage of the reactive group is occurring during reductive process. The NMR spectrum of the electrolysed dye confirms the previous results. The unidimensional (H NMR and gNOESY1D) and bidimensional (gCOSY, gHMBC and gHMQC) spectra of the original RB4 dye exhibited signals at $\delta 6.63$ 
(doublet, $J_{\text {meta }}=2 \mathrm{~Hz}$ ), $\delta 6.50$ (double doublet, $J_{\text {meta }}=2 \mathrm{~Hz}$ and $J_{\text {ortho }}=8 \mathrm{~Hz}$ ) and at $\delta 7,66$ (doublet, $J_{\text {ortho }}=8 \mathrm{~Hz}$ ) that represent the positions $\mathrm{H} 16, \mathrm{H} 12$ and $\mathrm{H} 13$ in the aromatic ring $\mathrm{C}$ (Fig. 1). After electrolysis is possible to observe the presence of the hydrogen at position $8(\mathrm{H} 8)$ by appearance of signal in $\delta=7.09$, suggesting that it exists the ortho correlation between the H8 and H7 in the molecule and there is an appearance of many signals due to extra interaction of hydrogen at position 6 , indicating rupture of the reactive group by $-\mathrm{C}-\mathrm{N}$ - bond cleavage in the $\mathrm{B}$ and $\mathrm{C}$ rings.

Although the color removal is important, the major practical interest in using the electrolytic method is complete mineralization of dye. In this context, experiments have been conducted by monitoring the total organic carbon (TOC) removal under the same operational conditions used for color removal. The TOC results obtained for aliquots of $2.5 \times 10^{-4} \mathrm{~mol} \mathrm{~L}^{-1} \mathrm{RB} 4$ in $\mathrm{HCl} / \mathrm{KCl} \mathrm{pH} 2.0$ were submitted to electrolytic treatment during $120 \mathrm{~min}$. $-0.60 \mathrm{~V}$ and the degradation measurement was obtained from the normalized equation: $\% \mathrm{TOC}=\mathrm{TOC}_{\text {initial }}-$ $\mathrm{TOC}_{\text {final }} / \mathrm{TOC}_{\text {final }} \times 100$. The results have shown $64 \%$ of the TOC removal, clearly indicating that the loss of the reactive group is preponderant during the reduction process confirming the previous results.

The results obtained indicate that RB4 dye reduction at reticulated glassy carbon electrode in acidic condition could form the basis of convert the anthraquinone group but the technique is not efficient to promote the total degradation of reactive dye bearing this chromophore group. Nevertheless, this study demonstrates that an electrolytic reduction leads to a significant decolorization and mineralization of the Reactive Blue 4 dye at very acidic conditions of $\mathrm{HCl} / \mathrm{KCl}$. The semiquinone specie is generated preponderantly during the electrolysis, but the hydroquinone derivative is also the final product after some time in solution.

Direct electro-oxidation of $2.5 \times 10^{-4} \mathrm{~mol} \mathrm{~L}^{-1} \mathrm{RB} 4$ dye solution in $0.2 \mathrm{~mol} \mathrm{~L}^{-1}$ $\mathrm{HCl} / \mathrm{KCl} \mathrm{pH} 2.0$ at $+1.0 \mathrm{~V}$ on reticulated vitreous carbon electrode was investigated in different times of electrolysis. After 3 hours from the end of the electrolysis, the catholytes were examined by spectrophotometry analysis and IR 
and NMR spectroscopy after previous extraction. The solution does not present any color modification. The UV-VIS spectrum after the electrolysis at any solution shows only a neglected decreasing of the absorption bands. The percentage of color removal is also shown in Table 2 taking the absorbance at $595 \mathrm{~nm}$. The results indicate that dye solution was not decolorized effectively in this electrolysis process using reticulated glassy carbon electrode, since the process involves only the oxidation of the amine group substituent in the molecule generating the imide derivative.

The IR spectra of the electrolysed product have shown the disappearance of the band at $881 \mathrm{~cm}^{-1}$ attributed to typical vibration of $\mathrm{C}-\mathrm{Cl}$ of the reactive group, indicating the occurrence of probable cleavage of the reactive group at acidic medium, as observed previously. Also, the NMR spectrum of the electrolysed dye confirms the previous results indicating the cleavage of the molecule, since the signals at $\delta=6.64, \delta=6.47$ and $\delta=7.61$ do not exist in the spectrum indicating rupture of the $\mathrm{C}-\mathrm{N}$ in the bond between $\mathrm{B}$ and $\mathrm{C}$ rings.

The TOC results were also obtained for aliquots of $2.5 \times 10^{-4} \mathrm{~mol} \mathrm{~L}^{-1} \mathrm{RB} 4$ in $\mathrm{HCl} / \mathrm{KCl} \mathrm{pH} 2.0$ submitted to electrolytic treatment during $120 \mathrm{~min}$ at potential of $+1.0 \mathrm{~V}$. Surprisingly, although the destruction of apparent color is negligible during the electrolysis process, the TOC removal was $56 \%$. The results indicate that the electro-oxidation of RB4 dye is not involving the chromophore group but the removal of TOC was somehow more influenced due to loss of reactive group. Usually, two different processes can occur at the electrode as a function of the anodic material: direct oxidation and indirect electrochemical oxidation via surface mediators. Taking into consideration that on reticulated vitreous carbon electrode the direct electro-oxidation was not successful for decolorization of the dye, an indirect method using metal oxide electrodes was tested.

It has been shown that the mineralization of organic compounds can be favored on dimensionally stable anodes due to the formation of hydroxyl radical as potent oxidant on the electrodic surface [23-26]. To check the relative importance of indirect oxidation on dye degradation, a series of experiment was performed 
using $\mathrm{SnO}_{2}$ based electrodes as alternative material for the electro-oxidation of RB4 solution.

Electrochemical studies with $\mathrm{SnO}_{2}$ electrodes, supported on titanium are very suitable for electrochemical decomposition of stable species [23]. It has also been shown that addition of $\mathrm{RuO}_{2}$ increases the electrode service life and decreases the water discharge potential [23-24]. For this reason, controlled potential electrolysis were performed for oxidation of $2.8 \times 10^{-3} \mathrm{~mol} \mathrm{~L}^{-1}$ solutions of RB4 dye using a $\left.\mathrm{Ti} / \mathrm{SnO}_{2} / \mathrm{SbOx} 3 \% \mathrm{~mol}\right) / \mathrm{RuO}_{2}(30 \% \mathrm{~mol})$ electrode at $+2.4 \mathrm{~V}$ in $\mathrm{Na}_{2} \mathrm{SO}_{4} 0.2 \mathrm{~mol} \mathrm{~L}{ }^{-1}$ solution at $\mathrm{pH}$ 2.0. These experimental conditions were previously optimized to get high efficiency conversion (23). The effect of time on the resulting product was evaluated interrupting the electrolysis in different times, and then realizing the spectrophotometric and TOC analysis.

Figure 6A shows the typical change in the UV-visible absorption spectra obtained for RB4 dye electrolyzed from 0 to $60 \mathrm{~min}$. of electrolysis on $\mathrm{SnO}_{2}$ based electrode. It can be seen that absorbance at $595 \mathrm{~nm}, 370 \mathrm{~nm}$ and $296 \mathrm{~nm}$ bands, characteristic of the anthraquinone group in the original dye, decreases markedly with time of electrolysis. In addition, also the other peak at $256 \mathrm{~nm}$, attributed to the aromatic character and chlorotriazine group, are completely vanished after 60 min of electrolysis. These results illustrate that dye degradation by electrolytic procedures is more effective than the results obtained when only dye oxidation or direct reduction are operating. Figure $6 \mathrm{~B}$ illustrates the performance of the $\mathrm{SnO}_{2}$ based electrode in color removal evaluated as Fractional Conversion $(f)$ of the dye and plotted in a time-dependent scale. The results pointed to $100 \%$ removal of color when $50 \mathrm{~mL}$ of the dye is electrolyzed for $20 \mathrm{~min}$ following the absorbance decreasing at $595 \mathrm{~nm}$ and $296 \mathrm{~nm}$. The dependence of the initial degradation rate on the dye concentration was evaluated from the initial rate of decrease of RB4 dye concentration in solutions and values of $5.6 \times 10^{-2} \mathrm{~mol} \mathrm{~L}^{-1} \mathrm{~min}^{-1}$ was estimated. The curves of $\ln \left(\mathrm{A}-\mathrm{A}_{\infty}\right)$ vs. time are linear and the degradation follows a first order kinetic with a rate constant shown in Table 2. The data presented above can lead to the conclusion that 
chromophore groups of the dye are promptly destroyed by indirect oxidation via $\mathrm{HO}^{\bullet}$ radicals generated on the electrode surface.
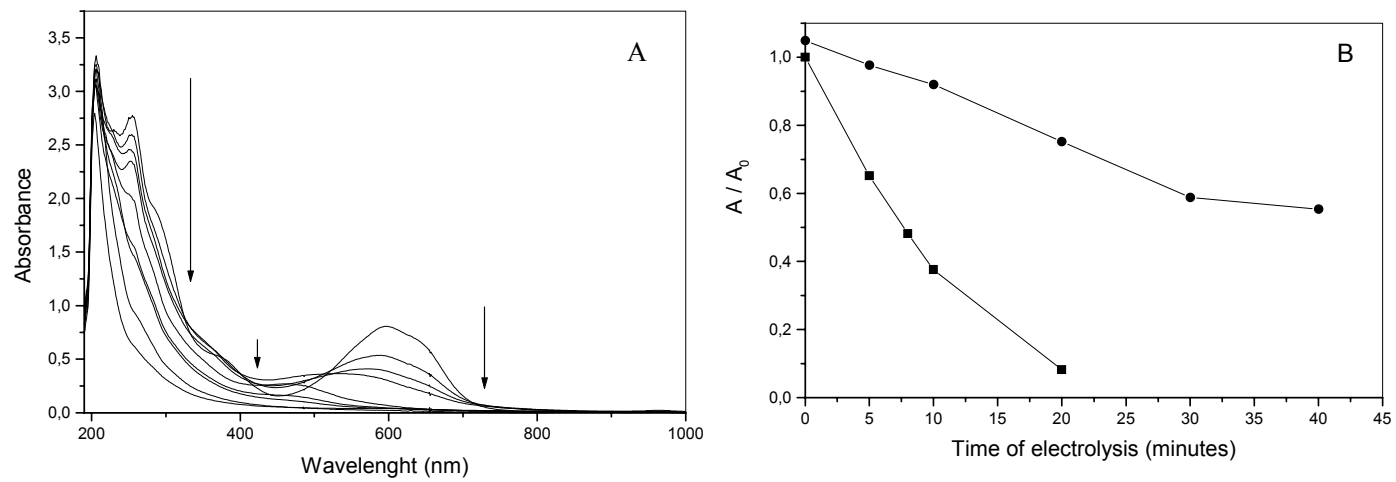

Figure 6. (A) Absorption spectra UV-VIS variation during electrolysis of $2.5 \times 10^{-4} \mathrm{~mol} \mathrm{~L}{ }^{-1} \mathrm{RB} 4$ dye at $+2.4 \mathrm{~V}$ in $\mathrm{Na}_{2} \mathrm{SO}_{4} 0.2 \mathrm{~mol} \mathrm{~L}{ }^{-1} \mathrm{pH} 2.0$ on $\mathrm{Ti} / \mathrm{SnO}_{2} / \mathrm{SbO}_{\mathrm{x}}(3 \% \mathrm{~mol}) / \mathrm{RuO}_{2}(30 \% \mathrm{~mol})$ electrode. Curve (1-9): $\mathrm{t}=0$ to $\mathrm{t}=60 \mathrm{~min}$. (B) Fractional conversion of $2.5 \times 10^{-4} \mathrm{~mol} \mathrm{~L}^{-1} \mathrm{RB} 4$ dye electrolysed on $\mathrm{Ti} / \mathrm{SnO}_{2} / \mathrm{SbO}_{\mathrm{x}}(3 \% \mathrm{~mol}) / \mathrm{RuO}_{2}(30 \% \mathrm{~mol})$ electrode in $\mathrm{Na}_{2} \mathrm{SO}_{4} 0.2 \mathrm{~mol} \mathrm{~L} \mathrm{~L}^{-1}$ $\mathrm{pH} 2.0,(-\mathbf{-}-) 597 \mathrm{~nm}$ and (-・-) $256 \mathrm{~nm}$.

On the other hand, Figure 7 shows the removal ratio of TOC for electrolysis interrupted at different times of oxidation on $\mathrm{SnO}_{2}$ based electrode. During the early part of the electrolysis the TOC removal drops rapidly up to $57.6 \%$. The fact that TOC can be eliminated indicates that great quantity of dye is mainly oxidized to $\mathrm{CO}_{2}$. During the second part of electrolysis, the decay in TOC is almost neglected and the TOC removal reaches a plateau at longer time of electrolysis. The reaction mechanism of the electrochemical oxidation of organic compounds is complex, but it is known from the literature [25-26] that usually the oxidation takes place in a first stage where hydroxyl radicals are produced by the electrochemical oxidation of water followed by subsequent organic oxidation at the electrode surface to $\mathrm{CO}_{2}$.

In agreement with the literature [23], this behavior could be indicative that oxidation reactions on $\mathrm{SnO}_{2}$ anode are specific due to the accumulation of $\mathrm{HO}^{\bullet}$ radicals on the surface, which leads to completion of the oxidation of organic species. However, when a constant current passes through the titanium electrode used as substrate it can be passivated due to $\mathrm{TiO}_{2}$ formation, which causes 
deactivation of the anode. Furthermore the $\mathrm{HO}^{\bullet}$ radicals adsorbed on the electrode surface can react with the active layer, leading to a decreasing in the electrolysis efficiency. On the other hand, this decrease of total organic carbon removal rate probably indicates the formation of more recalcitrant molecules.

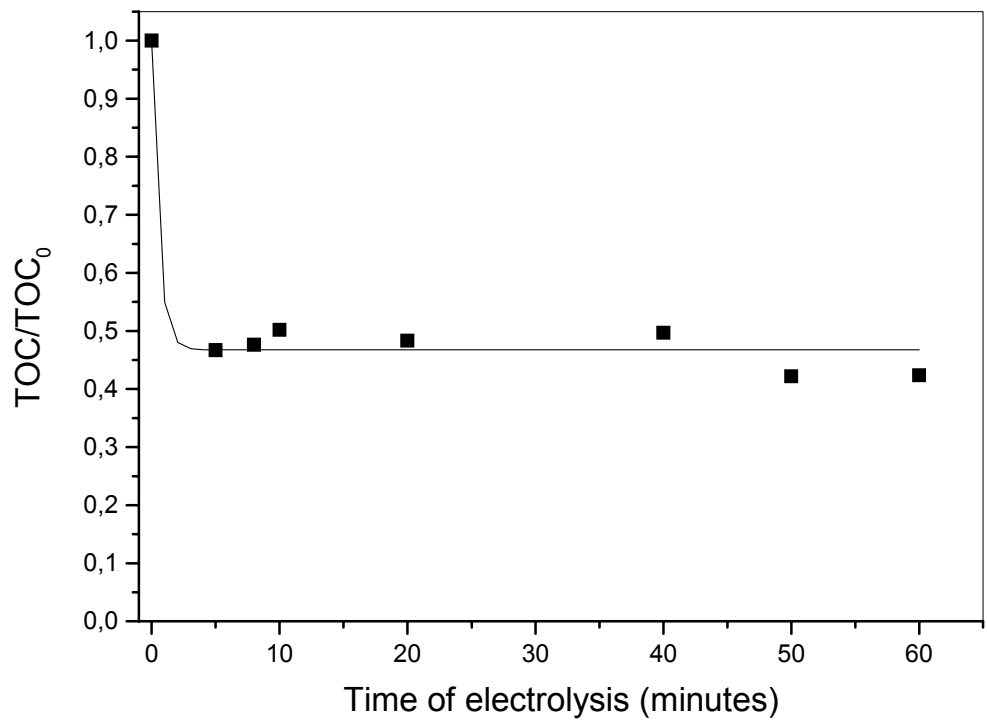

Figure 7. TOC degradation of RB4 dye electrolysed at $+2.4 \mathrm{~V}$ on $\mathrm{Ti} / \mathrm{SnO}_{2} / \mathrm{SbO}_{\mathrm{x}}(3 \% \mathrm{~mol}) / \mathrm{RuO}_{2}(30 \% \mathrm{~mol})$ electrode in $\mathrm{Na}_{2} \mathrm{SO}_{4} 0.2 \mathrm{~mol} \mathrm{~L}{ }^{-1} \mathrm{pH} 2.2$.

During the last two decades advanced oxidation process (AOPs), combinations of powerful oxidizing agents (catalytic initiators) with UV or near-UV light, have been applied for the removal of refractory organic pollutants and xenobiotics [27]. The high removal efficiencies of the Fenton process is based on $\mathrm{Fe}^{3+}$ (or $\left.\mathrm{Fe}^{2+}\right) / \mathrm{H}_{2} \mathrm{O}_{2} / h v$ forming a strong oxidising agent (hydroxyl radical) whose oxidation potential is very high $(2.8 \mathrm{~V})$ [27]. The main reaction which occurs in the solution during the Fenton process can be compiled as:

$$
\mathrm{Fe}^{2+}+\mathrm{H}_{2} \mathrm{O}_{2} \rightarrow \mathrm{Fe}^{3+}+\mathrm{OH}^{-}+\mathrm{OH}^{\bullet}
$$

This is a very simple way of producing $\mathrm{OH}$ radicals neither special reactants nor special apparatus being required. The rate of degradation of organic pollutant with Fenton process is strongly accelerated by irradiation with UV-VIS light [27]. This is an extension of Fenton process, which takes advantage from UVVIS light irradiation at wavelength values higher than $300 \mathrm{~nm}$. In these 
conditions, the photolysis of $\mathrm{Fe}^{3+}$ complexes allows $\mathrm{Fe}^{2+}$ regeneration and the occurrence of Fenton reactions due to the presence of $\mathrm{H}_{2} \mathrm{O}_{2}$ (eq. 1). The regeneration of free $\mathrm{Fe}^{2+}$ depends on the speed of $\mathrm{Fe}^{3+}$ ions reduction due to stable organic species or unstable products formed during photo-degradation $[27]$.

$$
\begin{gathered}
\mathrm{Fe}^{3+}+\mathrm{hv}+\mathrm{H}_{2} \mathrm{O} \rightarrow \mathrm{Fe}^{2+}+\mathrm{H}^{+}+\mathrm{HO}^{\bullet} \\
\mathrm{Fe}(\mathrm{OH})^{2+} \rightarrow \mathrm{Fe}^{2+}+\mathrm{HO}^{\bullet} \\
\mathrm{O}_{2}+\mathrm{Fe}^{2+} \rightarrow \mathrm{Fe}^{3+}+\mathrm{O}_{2}^{-} \\
2 \mathrm{O}_{2}^{-}+2 \mathrm{H}^{+} \rightarrow \mathrm{H}_{2} \mathrm{O}_{2}+\mathrm{O}_{2} \\
\mathrm{Fe}^{2+}+\mathrm{H}_{2} \mathrm{O}_{2} \rightarrow \mathrm{Fe}^{3+}+\mathrm{OH}^{\bullet}+\mathrm{OH}^{-} \\
\mathrm{HO}^{\bullet}+\text { dye } \rightarrow \text { products (colorless) }
\end{gathered}
$$

An improvement of photoassisted Fenton processes is the UVVIS/Ferrioxalate $/ \mathrm{H}_{2} \mathrm{O}_{2}$ system which has been very recently demonstrated to be more efficient than photo-Fenton for the abatement of organic pollutants [28]:

$$
\begin{gathered}
{\left[\mathrm{Fe}^{\mathrm{III}}\left(\mathrm{C}_{2} \mathrm{O}_{4}\right)_{3}\right]^{-3}+\mathrm{h} v \rightarrow\left[\mathrm{Fe}^{\mathrm{II}}\left(\mathrm{C}_{2} \mathrm{O}_{4}\right)_{2}\right]^{-2}+\mathrm{C}_{2} \mathrm{O}_{4}{ }^{\bullet}} \\
\mathrm{C}_{2} \mathrm{O}_{4}{ }^{\bullet-}+\left[\mathrm{Fe}^{\mathrm{III}}\left(\mathrm{C}_{2} \mathrm{O}_{4}\right)_{3}\right]^{-3} \rightarrow\left[\mathrm{Fe}^{\mathrm{II}}\left(\mathrm{C}_{2} \mathrm{O}_{4}\right)_{2}\right]^{-2}+\mathrm{C}_{2} \mathrm{O}_{4}^{-2}+2 \mathrm{CO}_{2} \\
\mathrm{C}_{2} \mathrm{O}_{4}{ }^{\bullet-}+\mathrm{O}_{2} \rightarrow \mathrm{O}_{2}^{\bullet-}+2 \mathrm{CO}_{2}
\end{gathered}
$$

Ferrioxalate is the oldest and well-known photoactive example of $\mathrm{Fe}^{3+}$ polycarboxylate complexes [29]. Irradiation of ferrioxalate in acidic solution generates carbon dioxide and ferrous ions, free or complexed with oxalate, which in combination with $\mathrm{H}_{2} \mathrm{O}_{2}$ provides a continuous source of Fenton's reagent. The performance of the Fenton process depends heavily on factors such as $\mathrm{pH}$ of the solution, quantity of hydrogen peroxide added and the dose of ferrioxalate [21]. The best experimental conditions for the photo Fenton process in the $1.0 \times 10^{-}$ ${ }^{4}$ mol $\mathrm{L}^{-1}$ dye degradation [30] proved to be the following: $\mathrm{pH} 2.5$, [hydrogen peroxide] $=7.00 \times 10^{-3} \mathrm{~mol} \mathrm{~L}^{-1}$ and [potassium ferrioxalate] $=0.70 \times 10^{-3} \mathrm{~mol} \mathrm{~L}^{-1}$. The strong absorption of the dye at concentration values higher than $0.10 \times 10^{-3}$ 
mol L $\mathrm{L}^{-1}$ minimizes the penetration of the irradiation and decreases the efficiency of the method. So, the performance of the photo-Fenton process for dye decolorization was investigated using initial concentration of $0.075 \times 10^{-3} \mathrm{~mol} \mathrm{~L}^{-1}$ and $0.10 \times 10^{-3} \mathrm{~mol} \mathrm{~L}^{-1} \mathrm{RB} 4$ dye, under photo irradiation by UV artificial light using the above experimental conditions. The photo-degradation based on TOC and the color removal measurements are shown in the Figure 8. As expected, the results demonstrate that the rate of photo-degradation and photo-decolorization is higher for diluted solution of $0.075 \times 10^{-3} \mathrm{~mol} \mathrm{~L}^{-1}$, but the results present a maximum of $80 \%$ of color removal and mineralization. The yellow coloration characteristic of hydroxy-compounds of iron generated during photo-irradiation are faded after a rest of 4 hours when there are visible precipitation of the residue and the results point out to $100 \%$ of decolorization.
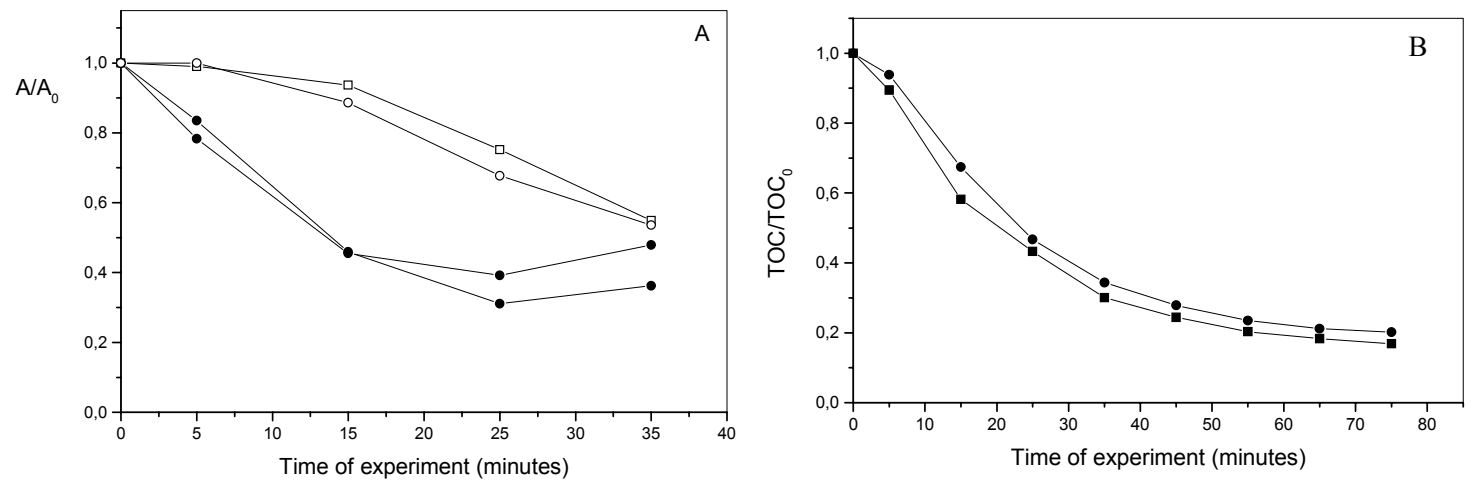

Figure 8. (A) Color removal for RB4 dye: (- $\square$ ) and (- - ) $0.075 \times 10^{-3} \mathrm{~mol}$ $\mathrm{L}^{-1}$ at $600 \mathrm{~nm}$; (- $\square$ ) and (-O-) $0.10 \times 10^{-3} \mathrm{~mol} \mathrm{~L}^{-1}$ at $203 \mathrm{~nm}$. (B) TOC removal obtained for RB4 dye (- $\longrightarrow$ ) $0.075 \times 10^{-3} \mathrm{~mol} \mathrm{~L}^{-1}$ and $(\longrightarrow \cdot-) 0.10 \times 10^{-3}$ mol L ${ }^{-1}$. Conditions: $[\mathrm{FeOx}]=1.00 \times 10^{-3} \mathrm{~mol} \mathrm{~L}^{-1},\left[\mathrm{H}_{2} \mathrm{O}_{2}\right]=10.0 \times 10^{-3} \mathrm{~mol} \mathrm{~L}^{-1}$.

\section{Conclusions}

In summary, it is clear that cathodic reduction using reticulated glassy carbon electrode in aqueous solution could form the basis to convert the anthraquinone group to hydroquinone, but the technique is not efficient to promote the total degradation of reactive dye bearing this chromophore group. Also, the use of direct anodic oxidation of the anthraquinone dyes on reticulated vitreous carbon electrode has not proved successful for total decolorization of the dye. The oxidation involves only the disubstituted amine group of the molecule generating 
the imide derivative. Even in acidic conditions, where the loss of reactive group leads to high decreasing in the TOC removal, the chromophore group is maintained in the molecule hindering significant removal of color solution.

The complete mineralization of the dye is not reached in $\mathrm{SnO} 2$ based electrodes but, in practice, the indirect oxidation of RB4 dye has shown promise degradation at a significant rate. The results demonstrate that direct electrochemical oxidation is not useful for color removal of dye solutions but the indirect electrochemical oxidation via $\mathrm{HO}^{\bullet}$ radicals offers one approach to developing new technology for removal of anthraquinone dye from the aqueous textile effluent. The $\mathrm{SnO}_{2}$ anode favors significant oxidation and total color removal, contrary to the reticulated glassy carbon electrode which leads only to selective oxidation and therefore no decolorization.

The photo-Fenton process proved to be a technique for RB4 dye degradation and for wastewater treatment when anthraquinone dyes are present. The potentiality of the method could be evaluated by the results leading to $80 \%$ of TOC degradation. Nevertheless, the method requires diluted solution and a rest time of at least 4 hours, when iron compounds can be removed as residual components generated during the chemical oxidation.

Despite the decolorization of textile waste is based on optimal solution acceptable to treatment plants [1], analysis of our results has shown that the chemical oxidation or electrochemical methods investigated do not assure complete degradation of this kind of dye. The combination of other techniques should be necessary before eventual discharge or recycling of process water since other recalcitrant side-products could be generated.

\section{Acknowledgements}

The authors thank FAPESP, CNPq and CAPES for the financial support of this work. 


\section{References}

1. H. Zollinger, Color in Chemistry, 2a ed, V.C.H.Publisher: New York, 1991.

2. K. Venkataraman, The Chemistry of Synthetic Dyes - The reactive Dyes, Vol.VI. Academic Press: New York, 1972.

3. C.A. Fewson, Trends Biotechnol. 6 (1988) 148-153.

4. E.A.Clarke, R. Anliker, Handbook of Environmental Chemistry, Vol.III, Part A, Antropogenic Compounds, Ed. by O. Hutizinger, 1980.

5. T. Robinson, Biores. Technol. 77 (2001) 247-255.

6. H.S. Lin, M.L. Chen, Water Res. 31 (1997) 868-876.

7. J. Sarasa, M.P. Roche, M.P. Ormad, E. Gimeno, A. Puig, J.L. Olivelleiro, Water Res. 32 (1998) 2721-2727.

8. J. Wu, M.A. Eiteman, S.E. Law, J. Environ. Eng. (1998) 272-277.

9. F.M. Saunders, P.J. Gould, R.C. Southerland, Water Res. 17 (1983) 14071419.

10. J. Carriere, J.P. Jones, A.D. Broadbent, Ozone Sci. Eng. 15 (1993) 189-200.

11. R. Pelegrini, P.P. Zamora, A.R. Andrade, J. Reyes, N. Duran, Appl. Catal. B: Environm. 22 (1999) 83-90.

12. J. Luo, M. Hepel, Electrochim. Acta 46 (2001) 2913-2932.

13. L Szpyrkowicz, C. Juzzolino, S. Daniele, Ind. Eng. Chem. Res. 39 (2000) 3241-3248.

14. L. Szpyrkowicz, C. Juzzolino, S.N. Kaul, Water Res. 35 (2001) 2129-2136.

15. J. Naumczyk, L. Szpyrkowicz, G.F. Zilio, Water Sci. Technol. 11 (1996) 1724.

16. M.V.B. Zanoni, A.G. Fogg, J. Barek, J. Zima, Anal. Chim. Acta 349 (1997) 101-108.

17. M.V.B. Zanoni, A.G. Fogg, C.C.I. Guaratini, Dyes and Pigments 50 (2001) $211-221$.

18. M.V.B. Zanoni, C.C.I. Guaratini, A.G. Fogg, Electroanal. 13, n.18 (2001) 1 9. 
19. M.V.B. Zanoni, P.A. Carneiro, M. Furlan, C.C.I. Guaratini, A.G. Fogg, Anal. Chim. Acta 385 (1999) 385-392.

20. J.G.E. Calvert, J.N. Pitts Jr., Photochemistry, New York: John Wiley \& Sons, 1996.

21. R.F.P. Nogueira, J.R. Guimarães, Water Res. 34, n. 3 (2000) 895-901.

22. M.M. Baizer, H. Lund, Organic Electrochemistry: an Introduction and a Guide, Marcel Dekker Inc.: New York, $2^{\text {nd }}$ ed., 1983.

23. P.T.A. Fugivara, A.A. Cardoso and A.V. Benedetti, Analyst 121 (1996) 541.

24. C. Iwakura, K. Sakamoto, J. Electrochem. Soc. 132 (1991) 858.

25. Ch. Comninellis, C. Pulgarin, J. Appl. Electrochem. 23 (1993) 108-112.

26. Ch. Comninellis, Electrochim. Acta 39 (1994) 1857-1861.

27. R. Andreozzi, V. Caprio, A. Insola, R. Marotta, Catal. Today 53 (1999) 5159.

28. A. Safarzadeh-Amiri, J.R. Bolton, S.R. Carter, J. Adv. Oxid. Technol. 1 (1996) 18-26.

29. V. Balzani, V. Carassiti, Photochemistry of Coordination Compound, Academic Press: New York, 1970.

30. P.A. Carneiro, M.V.B. Zanoni, unpublished results. 